\title{
EFFECT OF LIME-FIBER COLUMN ON COHESIVE SOILS IN TRIAXIAL TEST*
}

EIJEST

\begin{abstract}
Stone columns are considered as one of the well-accepted as well as cost effective ground improvement techniques for the stabilization of weak soil deposits. This paper discusses the results of a series of small-scale model column tests that were undertaken to investigate the behavior of lime columns reinforced with fibers. The tests focused on studying the effect of percentage of fibers used as reinforcement to the lime column, the diameter of column was varied in accordance to the diameter of test specimen. The effect of consolidation of soft soil due to inclusion of the stone columns on settlement response has also been included in the model. Plane strain conditions are considered for the loading and reinforced foundation soil system . It has been observed that if the soft soil is improved with reinforced lime columns, there is considerable reduction in the total settlement due to lime column itself. The increase of fiber percentage in the stone columns is effective for reducing the total settlement .Results from a series of laboratory model tests on unreinforced and reinforced lime column-improved soft clay with fibers have been presented. As compared to unimproved soft clay, the increase in load-carrying capacity under different improved ground conditions has been observed. Since introduction of fiber in lime improves its engineering behavior, unconsolidated undrained triaxial compression tests are conducted on clay samples with central lime- fiber core in order to explore the suitability of lime- fiber cores in stabilizing clay deposits. The results indicate that the deviator stress is improved by the placement of lime -fiber column.
\end{abstract}

Nagy A. El Mahallawy, Ahmad S. Rashed**

Structural Eng. Dept., El-shorouk Academy, Cairo, Egypt

KEYWORDS: Lime, Fiber, cohesive, Triaxial

EFFET DE LA CHAUX-DE FIBRE DE COLONNE SUR DES SOLS COHERENTS DANS LES TESTS TRIAXIAL

\section{RÉSUMÉ}

Colonnes en pierre sont considérés comme l'un des bien-acceptées ainsi que le coût des techniques efficaces d'amélioration des sols pour la stabilisation des dépôts de sol faibles.Cet article discute les résultats d'une série de tests à petite échelle colonne de modèle qui ont été prises pour enquêter sur le comportement des colonnes de chaux renforcés par des fibres. Les essais porté sur l'étude de l'effet du pourcentage de fibres de renfort utilisées comme à la colonne de chaux, le diamètre de la colonne a été modifiée conformément au diamètre de l'éprouvette. L'effet de la consolidation des sols mous à cause de l'inclusion des colonnes de pierre sur la réponse de règlement a également été inclus dans le modèle. Conditions de déformation plane sont considérés pour le chargement et le renforcement de système de sol de fondation. Il a été observé que si le sol mou est améliorée, avec des colonnes de chaux, il ya une réduction considérable dans le règlement total dû à la colonne de chaux elle-même. L'augmentation du pourcentage de fibres dans les colonnes de pierre est efficace pour réduire le total de la colonisation. Les résultats d'une série de tests en laboratoire sur des modèles non armé et armé de chaux colonne amélioration argile molle avec des fibres ont été présentés. Par rapport à l'argile molle en friche, l'augmentation de la capacité de charge dans différentes conditions de sol améliorées a été observée. Depuis l'introduction de fibres dans de la chaux améliore son comportement d'ingénierie, meubles essais triaxiaux non drainés sont réalisés sur des échantillons d'argile avec de la chaux centrale en fibre de base afin d'explorer la pertinence de la chaux-de fibres noyaux dans la stabilisation de dépôts d'argile. Les résultats indiquent que la contrainte déviatorique est améliorée par la mise en place de la chauxde fibres colonne.

MOTS-CLÉS: Lime, de fibres, de cohésion, triaxial

* Received: 1/1/2012, Accepted: 12/2/2012 (Original Paper)

** Contact author 


\section{INTRODUCTION}

Granular columns have been used in engineering practice to improve the bearing capacity of a weak or soft soil, and reduce the settlement of foundations resting on weak soil( Madhav et al., 1978). A granular column is constructed by filling a cylindrical cavity with granular material. The soil improvements via granular columns are achieved from accelerating the consolidation of weak soil due to the shortened drainage path, load carrying capacity increase and/or settlement reduction due to inclusion of stronger granular material. When vertical and corresponding lateral granular column deformations occur under a vertical load, the surrounding soil stratum generates additional confining pressure to the column.Test results demonstrated that reinforcement increased the peak strength and axial strain at failure.

Stone columns, one of the most commonly used soil improvement techniques, have been utilized worldwide to increase the bearing capacity of soft soils and reduce the settlement of superstructures constructed on them. Several researches have been carried out to study the behaviour of stone column-reinforced ground over the past three decades (Madhav and Vitkar, 1978; Balaam and Booker, 1981; Alamgir et al., 1996; Poorooshasb and Meyerhof, 1997; Lee and Pande, 1998; Muir-Wood et al., 2000; Ambily and Gandhi, 2007; Elshazly et al., 2007; Krishna et al., 2007; Black et al., 2007; Madhav et al., 2008; Bouassida et al., 2009).The degree of improvement of a soft soil by stone columns is due to two factors. The first one is inclusion of a stiffer column material (such as crushed stones, gravel,etc.) in the soft soil. This is largely reported in the literature,(e.g.Dhouib,2005) . The second factor is the densification of the surrounding soft soil during the installation of the vibrocompacted stone column itself and the subsequent consolidation process occurring in the soft soil before the final loading of the improved soil, Vautrain(1980), Wattes(2000). Bhaskar(2009) used the quarry dust column instead of stone column and reinforced with coir fiber. Sridharan et al. (2006) conducted studies on the shear strength of soil-quarry dust mixtures. An improvement in the bearing capacity and reduction in settlement of soft deposits can be effected by the installation of stone columns, Shroff( 2001).To minimize the ground settlement induced by the excavation, the column type of ground improvement has been used in many parts of the world, possibly due to the fact that this type of soil improvement is relatively easily produced and conceptually understood, Ou et al(1996). Common materials for columns are well graded lean sand, gravels or stones, hence the name stone columns.Different types of materials like lime, cement, flyash etc, are used. Randomly distributed fiber reinforcement can be advantageously employed as a good ground improvement technique. Santoni et al (2001), Vinod et al. (2007) conducted investigations to identify and quantify the effect of numerous variables on the performance of fiber reinforced material. Their investigations included laboratory experiments involving the stabilization of sand material with discrete fibers. Laboratory unconfined compression tests were performed to isolate the effect of sand type, fiber type, fiber length, and fiber dosage rate on the performance of fiber stabilized sands. The test results also indicate that the inclusion of synthetic fibers significantly improves the unconfined compressive strength of all types of sand used. Babu et al. (2005) conducted triaxial shear tests on fiber reinforced soil specimens. The tests were carried out at different fiber contents. It was observed that both strength and stiffness of soil increased considerably due to the inclusion of fibers .Major principal stress at failure increased .It is also reported that as fiber content increases the deviator stress also increases. Babu et al. (2005) attempted to study the compressibility behaviour of cochin marine clays improved with fiber. They conducted oedometer tests on specimens reinforced with randomly distributed fibers. Rao et al. (2005) conducted triaxial compression tests to determine the strength characteristics of sand reinforced with fiber and geotextiles. The results of the test indicated that the inclusion of fibers and geotextiles improves the performance 
of sand specimens. From their results it is observed that the inclusion of fibers increases the deviator stress developed at any strain level, which confirms the ability of fibres to strengthen the sands. Fiber reinforcement increases the shear strength parameters of cohesionless soil. The beneficial effects of randomly distributed fibers have been studied in many literatures. Unless the soil is to be mixed in place with the fibers, soil stabilization through inclusion of randomly oriented discrete fibers may be difficult, particularly when the vertical extent of soil to be irmproved is large. Ranjan et al. (1999) have analyzed the effect of columnar reinforcement using a sand-synthetic fiber composite on stabilization of soft clays. The present study examines whether columnar reinforcement of lime- fiber composite can be used for stabilization of soft clays.

\section{EXPERIMENTAL STUDY}

\section{A. Materials used}

1-Clay: The properties of clay are presented in Table 1.

\section{2- Lime:}

Crushed limestone has a uniformity coefficient of 20.26 and a coefficient of curvature of 1.37. The crushed limestone had $100 \%$ passing 37.5 $\mathrm{mm}$ opening sieve, $81 \%$ passing $19 \mathrm{~mm}$ opening sieve, $47 \%$ passing No.4 opening sieve, and $4 \%$ passing No. 200 opening sieve with an effective particle size (D10) of 0.465 $\mathrm{mm}$ and a mean particle size (D50) of 5.662 $\mathrm{mm}$. The maximum dry density of the soil was $22.1 \mathrm{KN} / \mathrm{m}^{3}$, with an optimum moisture content of $7.5 \%$, as determined by Standard Proctor test.

\section{3-Fibers:}

The properties of fibers used for the study are presented in Table 2.

\section{Table 1:Properties of Clay}

\begin{tabular}{|l|c|}
\hline Parameters & value \\
\hline Specific gravity & 2.62 \\
\hline Liquid Limit \% & 53.4 \\
\hline Plastic Limit \% & 21 \\
\hline Plasticity Index & 32.4 \\
\hline Optimum moisture content\% & 18.5 \\
\hline Maximum dry density & $16.7 \mathrm{KN} / \mathrm{m}^{3}$ \\
\hline $\begin{array}{l}\text { Bulk unit weight at } 30 \% \text { water } \\
\text { content }\end{array}$ & $19.8 \mathrm{KN} / \mathrm{m}^{3}$ \\
\hline
\end{tabular}

Table 2:Properties of Fibers

\begin{tabular}{|l|l|}
\hline Type & Polyester (synthetic) \\
\hline Cut length & $3 \mathrm{~mm}$ \\
\hline Coss- section & circular \\
\hline Diameter & $30-40$ \\
\hline Tensile elongation & \multicolumn{1}{|c|}{$>100 \%$} \\
\hline Tensile strength & $400-600 \mathrm{~N} / \mathrm{mm}^{2}$ \\
\hline colour & White \\
\hline
\end{tabular}

\section{B- Testing procedure}

Triaxial Compression tests were conducted on untreated clay samples and on clay samples reinforced using lime column reinforced with fibers. The deviator stresses at failure of different sample set up were determined from triaxial compression tests. For triaxial compression test, the soil samples are prepared at optimum moisture content (OMC) - maximum dry density (MDD) condition in a cylindrical split mould having diameter $38 \mathrm{~mm}$ and $76 \mathrm{~mm}$ height. For preparing untreated sample, the quantity of clay required to fill the mould at maximum dry density of $16.70 \mathrm{kN} / \mathrm{m}^{3}$ along with optimum moisture content of $18.5 \%$ was worked out. For preparing the clay samples with central core, a metal pipe which gives desired relative core area $(\mathrm{d} / \mathrm{D})$ ( i.e. the ratio of cross 


\section{EFFECT OF LIME-FIBER COLUMN ON COHESIVE SOILS IN TRIAXIAL TEST}

sectional area of the lime fiber core to that of the sample) is placed centrally in the mould. The quantity of clay required to fill the remaining volume of mould (excluding the volume of pipe) at maximum dry density of $16.70 \mathrm{kN} / \mathrm{m}^{3}$ along with optimum water content of $18.5 \%$ was worked out. Keeping the metal pipe centrally in the mould, clay is placed in the mould in layers around the pipe and compacted uniformly. The clay sample with central metal pipe (core) is thus prepared. The sample with core is extracted from the mould. The metal pipe is slowly removed and the core part is filled and compacted with lime or of lime with fiber mixture. The following procedure was used to mix the fibers into the lime for laboratory testing. First, an appropriate amount of lime was weighed and placed in a pan. Then, the water required to attain the target moisture content was measured and mixed into the lime in small increments to ensure uniform coverage. The fibers were weighed according to the desired dosage rate and mixed in small increments. The added fibers were mixed using hand. The fibers were continually mixed into the lime in small increments until all of the fibers were effectively distributed within the lime. Care was taken during the mixing process to ensure a uniform sand fiber mixture. During the filling process also, care was taken to ensure a homogeneous sand fiber mixture. The set up of the sample is shown in Fig. 1. Triaxial compression tests were conducted on samples prepared at OMC, maximum dry density condition. The variable parameters in the experimental study were fiber content, $d / D$ and confining stress. In this study fiber content of $0,0.5 \%, 1 \%, 1.5 \%, 2 \%$ and $3 \%$ were used. $0,0.1,0.15,0.20,0.25 \& 0.3$ were the relative diameter of column (core) to sample used. Confining stresses of $100 \mathrm{kPa}, 150 \mathrm{kPa}$, $200 \mathrm{kPa}$ and $250 \mathrm{kPa}$ were applied.

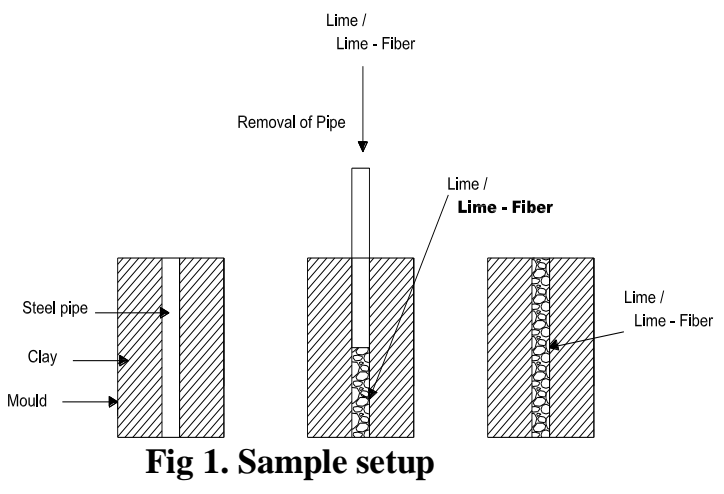

\section{RESULTS AND DISCUSSIONS}

Unconsolidated undrained triaxial compression test were performed on clay samples, with and without central sand-fibers column. Data obtained from triaxial compression tests were analyzed to study the effect of fiber content, relative diameter of column (core) to sample used and confining stress on reinforcing clay samples.

\subsection{Effect of Fiber Content on Deviator Stress at Failure}

For studying the effect of fiber content on the deviator stress at failure, experiments are conducted on clay samples with relative diameter of column to sample used $0.1,0.15,0.20,0.25$ and 0.3 and confining stress $150 \mathrm{kPa}$ and with different fiber contents. The results are shown in Fig. 2. From the results it is clear that the deviator stress at failure of clay reinforced with lime fiber column increases with the increase in fiber content up to $1.5 \%$ and then decreases. This reveals that the optimum fiber content in the lime fiber column is $1.5 \%$. Beyond that the volume occupied by fiber in the lime- fiber

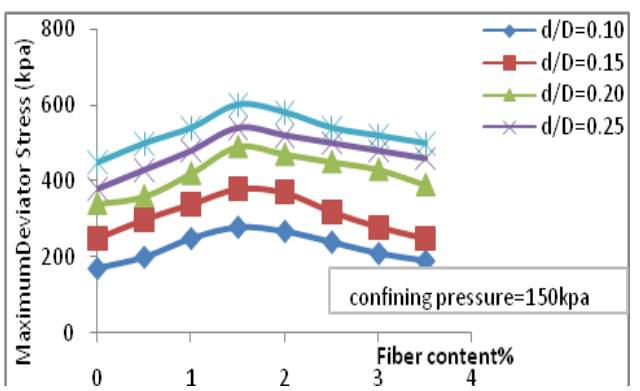

Fig. 2 Relation between Maximum Deviator Strees and Fiber\%. 


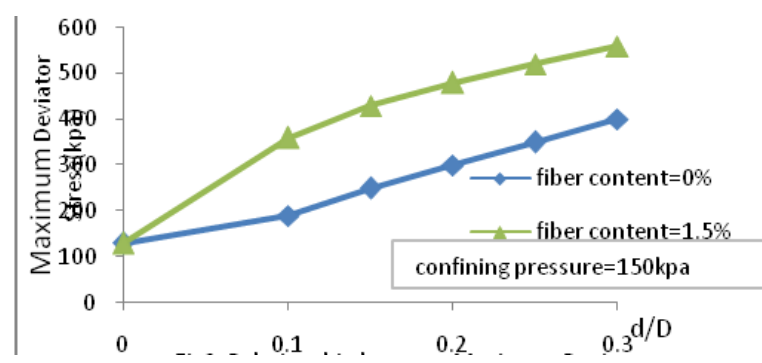

Fig. 3 Relation between Maximum Deviator Strees and $d / D$.

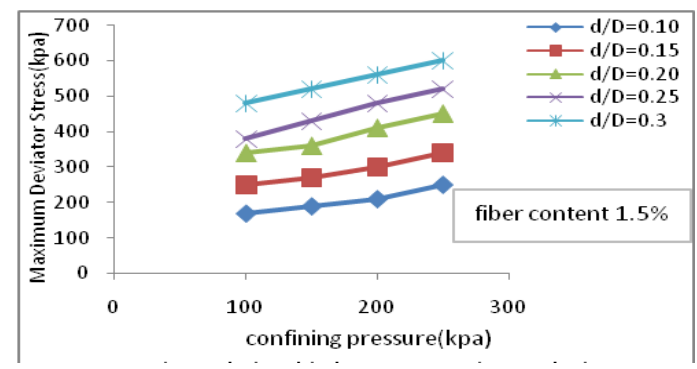

Fig. 4 Relation between Maximum Deviator Stress and Confining Pressure.

column increases, so as to develop fiber to fiber interaction than lime to fiber interaction. As a result the frictional resistance developed in the lime - fiber column decreases and hence the deviator stress at failure also decreases.

\subsection{Effect of Relative Column Area on Deviator Stress at Failure}

To study the effect of $\mathrm{d} / \mathrm{D}$ on deviator stress at failure, experiments were conducted on clay samples with fiber content $0 \%, 0.5 \%, 1 \%, 1.5 \%$, $2 \%$ and $3 \%$ and confining stresses of $100 \mathrm{kPa}$ $150 \mathrm{kPa}, 200 \mathrm{kPa}$ and $250 \mathrm{kPa}$ and $\mathrm{d} / \mathrm{D}$ of $0,0.1$, $0.15,0.20,0.25$ and 0.3 are used. From Fig. 3, it is clear that deviator stress at failure increases with increase in $d / D$. This is due to the reason that, as $d / D$ increases the quantity of weak soil replaced by good soil increases.

\subsection{Effect of Confining Stress on Deviator Stress at Failure}

To study the effect of confining pressure on deviator stress at failure, experiments were conducted on unsaturated clay samples with fiber content $1.5 \%$ and d/D: $0.1,0.15,0.2,0.25 \&$ 03 .Tests are conducted by varying the confining pressures. Confining pressures of $100 \mathrm{kPa}$, $150 \mathrm{kPa}, 200 \mathrm{kPa} \& 250 \mathrm{kPa}$ are applied. From Fig. 4, it is clear that deviator stress at failure increases with increase in confining pressure.

\subsection{Effect of reinforcement of clay beds on deviator stress at failure}

The effect of reinforcement on deviator stress at failure was studied by conducting experiments on unsaturated clay samples with different relative column area, fiber content and confining stress. $\mathrm{d} / \mathrm{D}$ of $0.1,0.15,0.20,0.25$ and 0.3 are used. Fiber content of $0 \%, 0.5 \%, 1 \%, 1.5 \%, 2 \%$ and $3 \%$ were used and confining pressure of, $100 \mathrm{kPa}, 150 \mathrm{kPa}, 200 \mathrm{kPa}$ and $250 \mathrm{kPa}$ were used. The result is shown in Figs5-9. From these figures, it is clear that the percentage increase increases with increase in $\mathrm{d} / \mathrm{D}$ and increases with fiber content up to $1.5 \%$ then decreases.

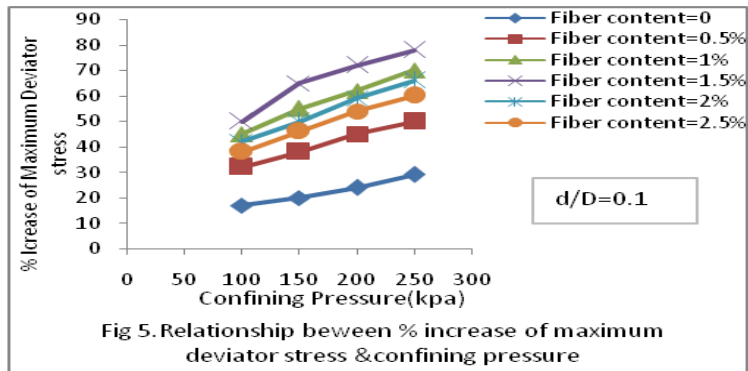

Fig. 5 Relation between \% Increase of Maximum Deviator Stress and Confining Pressure at $\mathrm{d} / \mathrm{D}=\mathbf{0 . 1}$.

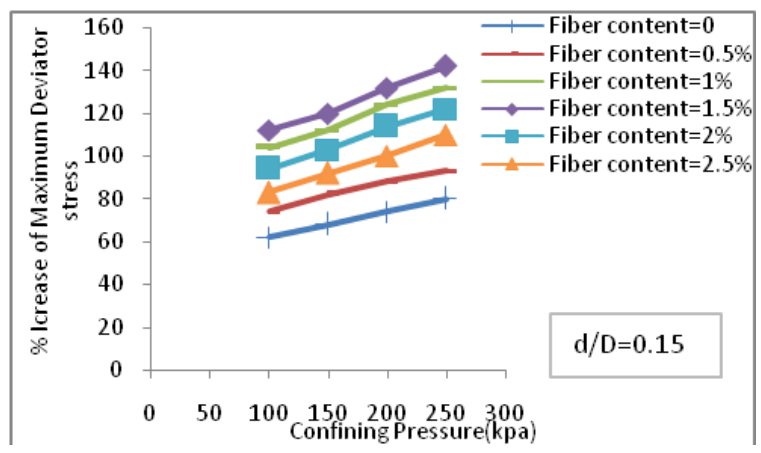

Fig. 6 Relation between \% Increase of Maximum Deviator Stress and Confining Pressure at $\mathrm{d} / \mathrm{D}=\mathbf{0 . 1 5}$. 


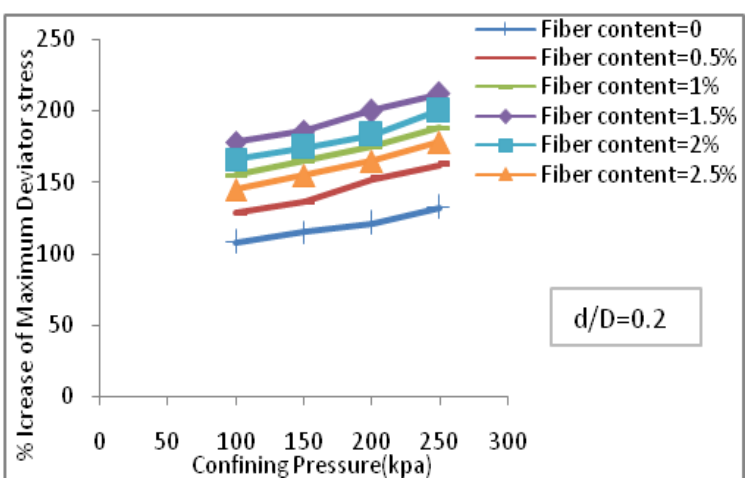

Fig. 7 Relation between \% Increase of Maximum Deviator Stress and Confining Pressure at $\mathrm{d} / \mathrm{D}=\mathbf{0 . 2}$.

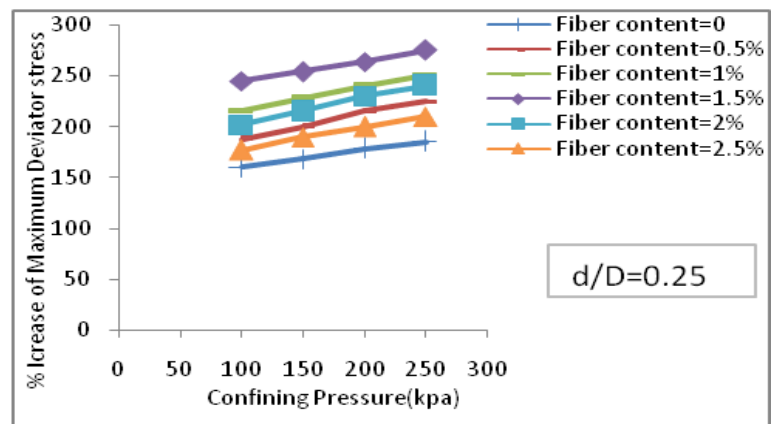

Fig. 8 Relation between \% Increase of Maximum Deviator Stress and Confining Pressure at $\mathrm{d} / \mathrm{D}=\mathbf{0 . 2 5}$.

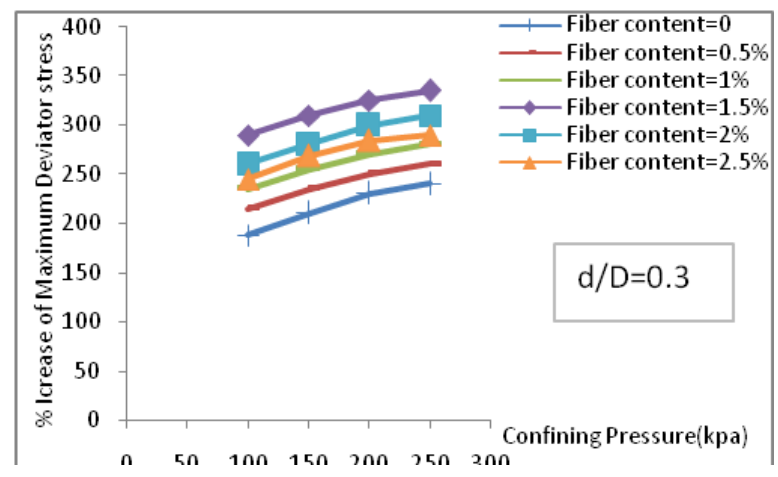

Fig. 9 Relation between \% Increase of Maximum Deviator Stress and Confining Pressure at $\mathrm{d} / \mathrm{D}=\mathbf{0 . 3}$.

\subsection{Effect of reinforcement of clay beds on stress-strain behavior}

In order to study the effect of reinforcement on stress strain behaviour experiments were conducted on clay samples without column, with lime column and with lime with fiber column. The variation in the stress strain behavior of clay for confining pressure of $250 \mathrm{kPa}$ and $\mathrm{d} / \mathrm{D}$ of 0.3 is shown in Fig. 10.

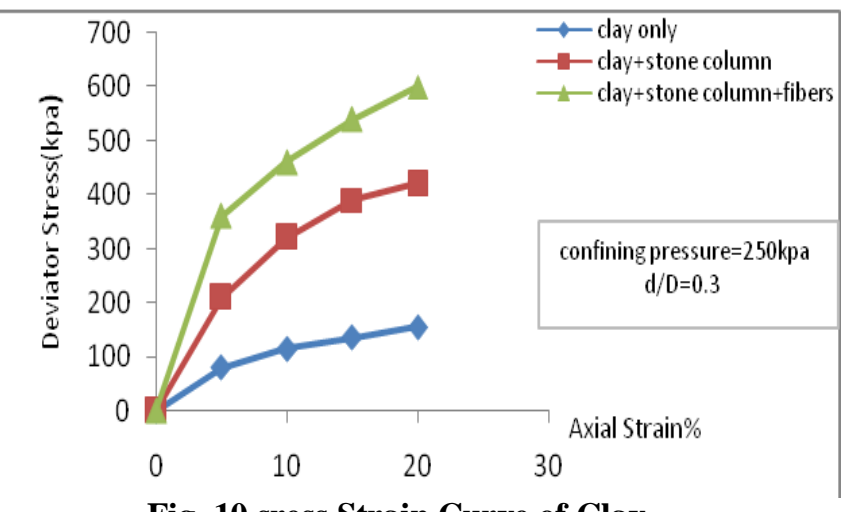

Fig. 10 sress Strain Curve of Clay.

\section{CONCLUSIONS}

The following conclusions which are valid for and limited to tiaxial test conditions were drawn from the experimental study carried out.

- The stress strain characteristics of clay increases with lime with fiber reinforcement cores.

- The deviator stress at failure of the soil increases with increase in fiber content. The optimum fiber content is obtained as $1.5 \%$.

- The percentage increase in deviator stress for treated samples is $335 \% \quad(\mathrm{~d} / \mathrm{D}=0.3$, Fiber content $=1.5 \%$, Confining pressure $=250 \mathrm{kPa}$ ) when compared with untreated clay samples.

- The deviator stress at failure of the soil increases with increase in confining pressure.

- The influence of confining pressure on deviator stress at failure (for a range of $100 \mathrm{kPa}$ to $250 \mathrm{kPa}$ ) is small when compared with the influence of $\mathrm{d} / \mathrm{D}$ and fiber content.

-Embedding a reinforced stone column in soil increases the stone column strength compared to a reinforced column subjected to constant confining pressure

\section{REFERENCES}

1- Alamgir, M., Miura, N., Poorooshasbh, H.B., Madhav, M.R., 1996. Deformation of soft groun 
columnar reinforced by columnar inclusions. Computers and Geotechnics 18, 261-290.

2- Ambily, AR, Gandhi, S.R., 2007. Behavior of stone columns based on experimental and FEM analysis. Journal of Geotechnical and Geoenvironmental Engineering (ASCE) 133, 405- 415.

3- Babu,S.G.L. and Vasudevan, A .K.(2005)' Strength and Stiffness Behaviour of Coir Fibre Reinforced Soil',Indian Geitechnical Conference,Ahmedabad,pp.241- 244.

4- Balaam, N.R, Booker, J.R, 1981. Analysis of rigid raft supported $\mathrm{b}$ granular piles. International Journal for Numerical and Analytical Methods in Geomechanics 5, 379403.

5- Bhaskar,A.B and Mereena,K.P(2009)

Triaxial

Compression of Clay Reinforced with Quarry Dust Fibre Column

6- Black, J.A., Sivakumar, V., Madhav, M.R., Hamill, G.A., 2007. Reinforced stone columns in weak deposits: laboratory model study. Journal of Geotechnical and Geoenvironmental Engineering (ASCE) 133, 1154-1161.

7- Bouassida, M., Jellali, B., Porbaha, A., 2009. Limit analysis of rigid foundations on Floating columns. International Journal of Geomechanics (ASCE) 9, 89- 101.

8- Dhouib A, Blondeau F. Colonnes ballastées. Edition Presses de l'ecole nationale des ponts et chausses,Paris;2005.

9- Elshazly, H., Hafez, D., Mossaad, M., 2007. Settlement of circular foundations on stone column reinforced grounds. Ground Improvement 11, 163-170.

10- Krishna, A.M., Madhav, M.R., Latha, G.M., 2007. Densification effect of granular piles on settlement response of treated ground. Ground Improvement 11, 127-136.

11- Lee, J.S., Pande, G.N., 1998. Analysis of stone-column reinforced foundations. International Journal for Numerical and Analytical Methods in Geomechanics 12, 1001-1020.

12- Madhav, M.R., Suresh, K., Peter E.C.N, 2008.
Effect of creep on response of granular pile reinforced ground. In: Indian Geotechnical Conference, India, pp. 276-280.

13- Muir-Wood, D., Hu, W., Nash, DEEr., 2000.

Group effects in stone colum foundations: model tests. Geotechnique 50, 689-698.

Ou,C.Y., Wu,T.S.and Hsieh,H.S (1996) 'Analysis of Deep Excavation with Column Type of Ground Improvement in Soft Clay', Journal of Geotechnical Engineering, Vol.122,No.9, pp 709-716

14- Poorooshasb, H.B., Meyerhof, G.G., 1997. Analysis of behavior of stone columns and lime columns.Computers and Geotechnics 20, 47-70.

15- Ranjan,G.and Charan,H.D.(1999)' Randomly

Distributed Fibre - Reinforced Soil-the State - of - the Art', Institution of Engineers (I) Journal -CV, Vol.79,pp. $91-100$.

16- Rao,G.V., Dutta, R.K.and Ujwala,D.(2005)'

Strength Characteristics of sand Reinforced with Coir Fibre and Coir Geotextiles', Electronic Journal of Geotechnical Engineering, Vol.10/G

17- Santoni,. R.L., Tingle.J.S., Webster.S.., (2001)' Engineering Properties of SandFibre Mixtures for Road Construction' Journal of Geotechnical and Geoenvironmental Engineering ASCE, Vol. 127, No.3 , pp. $258-268$.

18- Shroff,A.V.,(2001)'Ground Improvement Techniques', "The New Millenium Conference", 14-16 Dec.,Indore(M.P),India. 19- Sridharan, A. and Soosan,T., G.(2005), "Utilization of Quarry Dust to improve the Geotechnical Properties of Soils in Highway Construction", Canadian Geotechnical Journal, Vol.28, pp.391-400

20- Sridharan, A.,Soosan, T.,G. and Babu,T.,J. (2006), "Shear Strength Studies on SoilQuarry Dust Mixtures", Journal of Geotechnical and Geological Engineering, Vol.24, pp.1163-1179

21- Vautrain J. Comportement et dimensionnement des colonnes ballastces. Revue Française 
de GCotech 1980;11:59 73 .

22- Vinod, P., Ajitha Bhaskar,and C.

S.LekshmiT

(2007), "Triaxial Compression of Clay

Reinforced with sand-coir fibre core",

GeotechnicalTesting Journal, Vol. 30,No. 4

College of Engineering Trivandrum

23- Wattes KS. Johnson D, Wood LA, Saadi A.

An

instrumented trial of vibro ground

treatment supporting strip foundations in a

variable fill. Geotechnique 2000; 50(6): 699-

708 . 